\title{
MEMORIA DE LO INFANTIL: HUELLAS, MANCHAS Y JIRONES
}

\section{CHILDHOOD MEMORY: TRACES, MARKS AND FRAGMENTS}

\section{KAREN MONSALVE}

Psicoanalista practicante en Buenos Aires, Lic. En Psicología Universidad Nacional de La Plata (UNLP). Miembro del Centro Descartes. Co- fundadora de la Delegación Pilar del Instituto Oscar Masotta y Asociación de Psicoanálisis de Pilar (APPIL)

\section{Abstract: Commentary on the work of the artist Claudio Gallina}

Resumen: Comen

Palabras Claves: Infancia - Recuerdo - Escuela - Mancha - Mirada

\section{FRAGMENTOS DE (BIO)GRAFÍA}

102 Artista contemporáneo, nacido en 1964, en la ciudad de Buenos Aires, Claudio Gallina destaca de su pasaje por la Escuela Nacional de Bellas Artes Prilidiano Pueyrredón -donde comenzó su formación artística- su mirada dirigida a Latinoamérica, a diferencia de la tradición europea que ha marcado históricamente la tendencia de sus compañeros de estudios. Fue alumno de Osvaldo Attila y Armando Sapia, entre otros artistas.

Se suman a esta influencia la música, la literatura (Borges, Cortázar, Tenesee Williams, Italo Calvino), y una concepción particular de la memoria y el recuerdo. También hay un cruce de esta idea con su experiencia vivida: recuerda sus 17 años como el momento de despertar a la realidad de una dictadura que aún no había terminado, y que sin haberlo advertido atravesó toda su vida escolar. Además, el episodio de "La noche de los lápices" -en que alumnos de secundaria cercanos a su edad en ese momento, fueron secuestrados y desaparecidos a causa de su lucha estudiantildejó una impronta que en su obra se refleja en la serie de cuadros sobre escenas escolares. Hay alusiones en el juego del gallito ciego, o el de las escondidas. Según las palabras del propio artista: "La obra que mandé a Panamá 1 se llama Silen- cio Abismal, porque todo en ese momento era silencio, uno no podía hablar, no podía discutir, no podía opinar. Traté de hacerlo de una manera poética, porque con la obra se debe hacer poesía, no ser literal. Por ello digo que mi obra tiene capas. Cada uno lee la capa que quiere, hay gente que lee la primera capa y dice ¡Ay que lindos los chicos! ¡la escuela, cuantos recuerdos me trae!, otros leen otra capa con la que se sienten identificados, ven otras cosas, ¡es el arte!” 2.

Realizó exposiciones individuales y colectivas en Argentina, México, Colombia, Puerto Rico, Estados Unidos, Perú, España, Chile, España, Inglaterra, Panamá. Participó en Bienales y Ferias internacionales de Arte: Arte Ba, Art Miami, Art Chicago, Art Madrid, Pinta de Nueva York, Art Bo Colombia, Bienal de Panamá entre otras. Realizó murales por la memoria en la Ciudad de Buenos Aires e intervino la estación de subterráneos Acoyte, en conmemoración de los 100 años de su creación.

\section{PRIMER CAPA: OBJETOS INTERVENIDOS Y RECUERDOS INFANTILES}

Además de los buenos oficios de pintor bien formado en la técnica, hay una originalidad en las 
obras de Claudio Gallina: el uso de objetos en desuso, rescatados e intervenidos con la pintura, sin ocultar del todo su material vivo, hecho de las experiencias que los atravesaron. Pupitres, cuadernos, libretas, hojas de carpeta (en ocasiones varias conformando un gran collage desarmable), son soporte material para la creación de las escenas representadas en la pintura.

El material, rescatado de escuelas de su ciudad, escuelas que evocaron las escuelas públicas por la que transitó, fue una fuente de inspiración para trabajar la memoria de lo infantil, en particular, lo escolar. Allí hay una historia, han pasado generaciones, han dejado sus mensajes, el artista lo deja hablar.

En esa rememoración, hay un primer efecto identificatorio que apela a la experiencia común: pizarrones y tizas, guardapolvos blancos, los juegos, el recreo. "Cada escena es una exploración hacia el pasado, hacia los recuerdos de infancia atizados por una nostalgiosa felicidad" 3 .

Pero sabemos, por Sigmund Freud, que no hay recuerdos de la infancia, sino recuerdos sobre la infancia. Son fragmentos, jirones extraídos a la historia, recolectados, alterados, falseados, al servicio de deseos más tardíos, de modo que resulta difícil diferenciarlo de las fantasías. En otras palabras, recuerdos encubridores. No porque encubran una verdad originaria, sino porque el disfraz es el modo de presentación de la verdad inconsciente.

\section{SEGUNDA CAPA: LA PIZARRA MÁGICA}

Así, ese dispositivo (algo vetusto en estos tiempos, pero que no pierde su eficacia de metáfora) utilizado por Freud para reunir las dos operaciones de la memoria que no pueden articularse en un solo plano -huellas duraderas y una superficie receptiva ilimitada- permite mirar las escenas escolares de Claudio Gallina apelando a diversos planos de lectura. Lecturas a descubrir en cada ocasión, ya que el propio artista revela cómo cada trabajo es el planteo de una pregunta, que la pintura acabada responderá, o no. Y además la respuesta varía según su interpretante, es decir, deja la obra abierta a la interpretación de sus receptores.

"Una obra de Gallina tiene varias lecturas, y las capas de sus múltiples significados sólo se abren con el tiempo y la paciencia de la observación"4, dice un comentarista.

Por ejemplo, donde se ve un juego de niños ha- ciendo equilibrio, acude el sentido del equilibrio inestable de la educación pública. O la educación como escalera al ascenso social, para luego saltar a un mundo donde se debe "resolver, con $\$ 3200$ por mes, comprar pan para una familia a $\$ 40$ el kg" (ilustración de tapa).

También están las pasiones, las complicidades, el lazo con los otros, no siempre cándido ni inocente. Los miedos, los monstruos, la segregación. Es decir, lo que escapa al empuje civilizatorio de la escuela. “(...) casi parece que escuchamos voces que subliman ansiedades, de imágenes que se hacen eco del tiempo y evocan historias subjetivas en las que se esconden tanto la tragedia como el juego infantil, el aquelarre y la admonición, la lucha y la entereza de quien, categórico en sus dudas, se corrige sin titubear y hace de las figuras de otras gentes, su más vivo autorretrato."5.

Porque el espacio que delimita la escena en cuestión es el del sujeto, representado en los actores que participan de las escenas, pero también en la organización del espacio, sus elementos, y fundamentalmente, en la posición del ojo que capta el instante como si fuera una cámara fotográfica, otro rasgo particular de las pinturas de Claudio Gallina.

\section{MÁS CAPAS...: LA MANCHA}

Casi todas las imágenes cuasi fotográficas de los cuadros escolares emergen de una mancha de tinta, siguiendo la visión de Leonardo.6 Cómo no evocar en qué terminaba la mancha de tinta en nuestros cuadernos de la primaria: en un enorme agujero!

"Introducida la angustia de castración entre la mirada y el ojo, es el mimetismo lo que pasa a primer plano"7. Es la lectura de Germán García, de la esquizia del ojo y la mirada planteada por Jacques Lacan.

La mancha, en el fenómeno natural del mimetismo, es señuelo, determinado por la inserción de la mirada en el campo de la visión. Pero que el sujeto del deseo no queda atrapado en esta captura imaginaria, es lo que demuestra por ejemplo el efecto del trompe-l'oeil ("trampantojo"), ese truco pictórico que caza la mirada para luego, por un pequeño desplazamiento, permitir que se descubra la trampa.

Hay algo de este truco en las pinturas de Claudio Gallina. Como advierte Germán García, el pin- 
tor (a diferencia del actor, que quiere ser mirado) "invita a deponer la mirada como se deponen las armas", lo que convierte a la contemplación del cuadro en algo pacificador, que se detiene en la luz, la belleza y el orden del cuadro. Luz y belleza sobre el fondo de una oscura mancha. Irresistible!

Nota

1. Se refiere a su participación en la Bienal de Panamá, en 2013

2. En entrevista realizada en Caracas por Raúl Figueiras, julio de 2013. En: http//claudiogallina.com/entrevista-por-raul-figueira-caracas/

3. Sánchez, Julio: "Una visión totalizadora", diciembre de 2016. En http:// claudiogallina.com/una-vision-totalizadora-julio-sanchez/

4. Toca, Santiago: Los recuerdos presentes de Claudio Gallina, Ciudad de México, febrero de 2004. En http://claudiogallina.com/los-recuerdospresentes-de-claudio-gallina/

5. Figueiras, Raúl: Caracas, julio de 2013

6. Según el comentario de Alvino Dieguez Videla, Leonardo Da Vinci veía en las manchas de un muro los trazos de grandiosas composiciones plásticas. A lo que agrega: "Nuestro pintor ve en la mancha inicial las zonas más oscuras de nuestra realidad y luego las ilumina con esos guardapolvos blancos conmovedoramente vulnerables. En http://claudiogallina.com/ todo-esta-a-la-vista-por-albino-dieguez-videla-argentina/

7. García, Germán: "Sobre du semblant" (1993), en D'escolar, Ed. AtuelAnáfora, 2000. 